\title{
Risk Assessment in Construction Projects During Construction Period
}

\author{
P. Dayakar, K. Venkat Raman, R.Venkatakrishnaiah
}

\begin{abstract}
At whatever point a Construction venture is started parcel of vulnerability and hazard is normal before the finishing of the undertaking. Because of interest and innovation the development business has changed altogether in the course of recent years. To beat these dangers the hazard evaluation is required. Hazard evaluation is an apparatus to distinguish those dangers in a venture. Hazard evaluation is characterized as a strategy that expects to recognize and assess the dangers. In this examination a poll study is made by staff meeting. Factual bundle for sociology is utilized to dissect the poll. From the investigation it is finished up the need to give more consideration on work inadequacy, hardware disappointment and blunders in structure and attracting when contrasted with different dangers. Deficiency of able specialists is the significant hazard looked by practically every one of the organizations
\end{abstract}

\section{Keywords - Vulnerability, Hazard, Investigation}

\section{INTRODUCTION}

Development ventures are typically portrayed by many changing dangers. A hazard all through the development procedure is a significant and focal component averting undesirable results. Hazard is a multi-feature idea. With regards to development industry, it could be the probability of the event of a positive factor or mix of variables which happen during the entire procedure of development. Past investigate recommends that development movement is especially dependent upon a bigger number of dangers than different business exercises on account of its intricacy, a development venture as a rule requires a social affair of individuals with various abilities and premiums and the coordination of a wide scope of unique, yet interrelated, exercises. A lot of hazard examination systems and instruments are accessible for the administration of dangers[1]-[4]. On a basic level, each hazard investigation system has its very own quality and shortcoming. The idea of dangers viable is determinant in the choice of demonstrating and examination methods. (Daniel Baloi)

\section{METHODOLOGY}

Strategy is a manner by which the entirety of the strategies, techniques and methods received to gather information,

Revised Manuscript Received on October 22, 2019.

P. Dayakar, Department of Civil Engineering, Bharath Institute of Higher Education and Research, Chennai , India. Email: dayakarpitti@yahoo.co.in

K. Venkat Raman, Department of Civil Engineering, Bharath Institute of Higher Education and Research, Chennai , India. Email: venkatraman.civil@bharathuniv.ac.in

R.Venkatakrishnaiah, Department of Civil Engineering, Bharath Institute of Higher Education and Research, Chennai, India. Email: venkatapec@gmail.com examine information and give proposals. Powerful approach is utilized all through this examination to guarantee every one of the information and data assembled is dependable and it is deliberately gathered and investigated. An organized meeting survey is arranged and is utilized to gather the information from the work force occupied with development ventures. While gathering the information care is taken to guarantee the dependability of people giving the information[5]-[9].

\section{METHOD OF SURVEYING}

The general system of this examination depends to a great extent on the poll study which was gathered from the nearby building temporary workers who are doing development extends in and around Chennai, TamilNadu, by email or by staff meeting. The development activities of various sizes are taken for the investigation.

\section{RESULTS AND DISCUSSION}

Absolutely for thirty five organizations the polls are given, out of which twenty five gave a viable answer. In this manner the reaction rate is $82 \%$ which is viewed as a decent reaction in this sort of overview. All the poll review was done from venture administrator or undertaking engineer, site specialist of the task at the building site. Now and again, expert offered the responses in the interest of their customers, both from the proprietor and the temporary worker side. Indeed, even email answer was acknowledged since it was hard to get the immediate coordinated gathering with the Project directors[10]-[11].

The subtleties of results are appeared in the table 1. To the extent the respondent is concerned the expansion of material cost has the most extreme hazard rating. Different dangers which have most extreme hazard rating are venture delay, increment of work costs, high overhead cost, lack of capable specialists, time requirements, misfortune because of ascend in fuel costs, Increase of embellishment offices cost, Wastage of materials by laborers and Surplus materials taking care of[12]-[13]. The least hazard rating given by the two proprietors and contactors are misfortune acquired because of political changes, Unknown site physical conditions, Loss because of organization for late endorsements, Site good ways from urban territory and lack in supply of power.

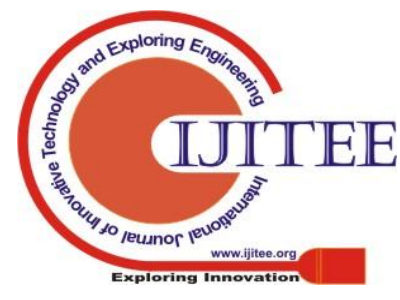


Table - 1 Overall rating of Risks

\begin{tabular}{|c|c|c|c|}
\hline Rank & Sub Risk Factors & Mean & $\begin{array}{l}\text { Standard } \\
\text { Deriation }\end{array}$ \\
\hline & CONSTRUCTIONRISK & 3.92 & .954 \\
\hline 1 & Labor insuficiency & 3.20 & 1.152 \\
\hline 3 & Accidents on site & 2.92 & 1.152 \\
\hline 6 & Equipment failures & 2.88 & 1.34 \\
\hline 7 & Errons in design dratrings & 3.24 & 1.128 \\
\hline 2 & High degres of difficulty in construction & 3 & 1.080 \\
\hline 5 & Incompetence of transportation facilities & 2.80 & 1.080 \\
\hline 8 & Materials shortagge & 2.96 & 1.080 \\
\hline 5 & Poor quality of procured materials & 2.92 & 1.369 \\
\hline 6 & Dua to water & 2.96 & 1.152 \\
\hline 4 & Dua to fuel & 2.60 & 1.098 \\
\hline 11 & Dus to Electricity & 2.72 & 0.866 \\
\hline 10 & Unlnown site physical conditions & 2.84 & 1.100 \\
\hline 8 & Shortage of skillful workers & 3.20 & 1.28 \\
\hline 3 & Wastage of materials by workers & 2.84 & 1.18 \\
\hline 8 & Theft of materials at site & 2.72 & 0.850 \\
\hline \multirow[t]{2}{*}{10} & Surplus materials handling & 3.92 & .954 \\
\hline & ENTIRONMENTAL RISK & & \\
\hline 9 & Any adverse impact on project dus to climatic conditions & 2.80 & 1.021 \\
\hline 16 & Any impact on the environment dus to the project & 2.24 & 1.118 \\
\hline \multirow[t]{2}{*}{13} & working environment to the worker & 2.40 & 1.225 \\
\hline & MANAGEMENT RISK & & \\
\hline 12 & Short tendering time & 2.24 & 1.085 \\
\hline 12 & Past experience in similar projects & 2.56 & 1.325 \\
\hline 8 & Improper project fassibility study & 2.56 & 1.53 \\
\hline 15 & Improper projet planning and budgeting & 2.842 & 1.28 \\
\hline 10 & Improper project organization structures & 2.292 & 1.369 \\
\hline 8 & Communication betwean clients & 2.72 & 1.152 \\
\hline 9 & Time constraint & 2.84 & 0.954 \\
\hline 9 & Project delay & 2.80 & 0.957 \\
\hline
\end{tabular}

\section{A. Construction Risks}

Wastage of materials by laborers, Surplus materials taking care of, Errors in plan drawings, Theft of materials at site, Materials lack, and High level of trouble in development are high positioning in this sort of dangers. The kinds of Construction hazard as appeared in table 2 and the relating bar graph is appeared in figure 1.

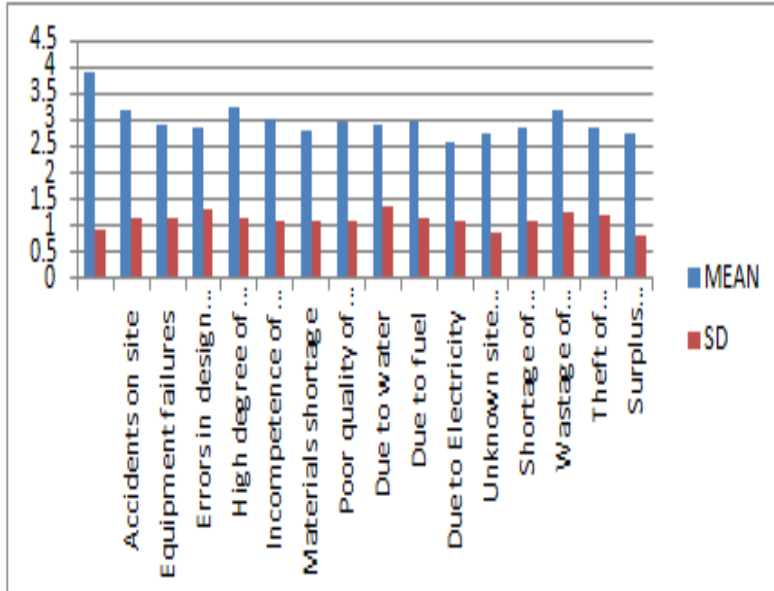

Figure - 1 Construction risks
Table - 2 Construction Risks

\begin{tabular}{|c|l|c|c|}
\hline Rank & \multicolumn{1}{|c|}{ Construction risk } & Mean & Standard Deviation \\
\hline 1 & Lahour insufficiency & 3.92 & .954 \\
\hline 3 & Accidents on site & 3.20 & 1.152 \\
\hline 6 & Equipment failures & 2.92 & 1.152 \\
\hline 7 & Errors in design drawings & 2.88 & 1.34 \\
\hline 2 & High degree of difficulty in construction & 3.24 & 1.128 \\
\hline 5 & Incompetence of transportation facilities & 3 & 1.080 \\
\hline 8 & Materials shortage & 2.80 & 1.080 \\
\hline 5 & Poor quality of procured materials & 2.96 & 1.080 \\
\hline 6 & Due to water & 2.92 & 1.369 \\
\hline 4 & Due to fuel & 2.96 & 1.152 \\
\hline 11 & Due to Electricity & 2.60 & 1.098 \\
\hline 10 & Unknown site physical conditions & 2.72 & 0.866 \\
\hline 8 & Shortage of akillful workers & 2.84 & 1.100 \\
\hline 3 & Wastage of materials by workers & 3.20 & 1.28 \\
\hline 8 & Theft of materials at site & 2.84 & 1.18 \\
\hline 10 & Surplus materials handling & 2.72 & 0.850 \\
\hline
\end{tabular}

\section{B. Environmental Risks}

During stormy season dormant of water in establishment in the beginning phase of the venture is an extraordinary burden for the development organizations. For the laborers working under the immediate daylight is troublesome, so security head protectors are given in certain organizations. Enormous organizations are tolerating that there are not many ecological impacts because of their task. The sorts of Environmental hazard as appeared in table 3 and the comparing bar outline is appeared in figure 2

\begin{tabular}{|c|l|c|c|}
\hline Rank & \multicolumn{1}{|c|}{ Environmental risk } & Mean & $\begin{array}{c}\text { Standard } \\
\text { Deriation }\end{array}$ \\
\hline 9 & Any adverse impact on project due to climatic conditions & 2.80 & 1.021 \\
\hline 16 & Any impact on the environment due to the project & 2.24 & 1.118 \\
\hline 13 & working environment to the worker & 2.40 & 1.225 \\
\hline
\end{tabular}

Table 3 Environmental risk

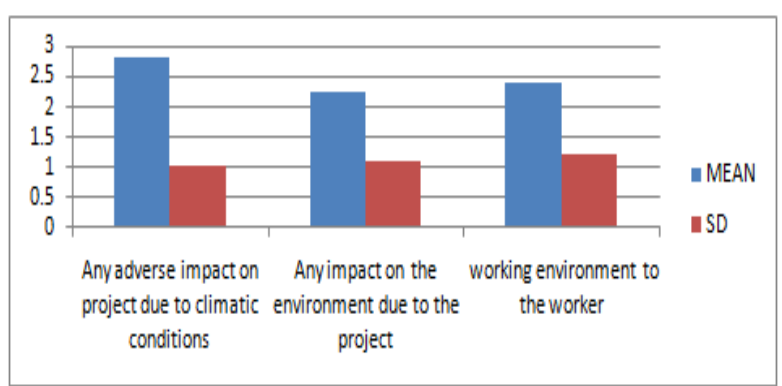

Figure2 - Bar Chart for Environmental Risk

\section{Management Risks}

The overview shows that there are the board sorts of hazard. Task postpone and time imperatives are exceptionally influenced. The sorts of hazard as appeared in table 4 and the bar graph has been drawn for the kind of the board chance 
versus mean and standard deviation is appeared in fig. 4

\begin{tabular}{|c|l|c|c|}
\hline Rank & \multicolumn{1}{|c|}{ Management risk } & Mean & Standard Deviation \\
\hline 12 & Short tendering time & 2.24 & 1.085 \\
\hline 12 & Past experience in similar projects & 2.56 & 1.325 \\
\hline 8 & Improper project feasibility study & 2.56 & 1.53 \\
\hline 15 & Improper project planning and budgeting & 2.842 & 1.28 \\
\hline 10 & Improper project organization structures & 2.292 & 1.369 \\
\hline 8 & Communication between clients & 2.72 & 1.152 \\
\hline 9 & Time constraint & 2.84 & 0.954 \\
\hline 9 & Project delay & 2.80 & 0.957 \\
\hline
\end{tabular}

Table 4 - Management risk

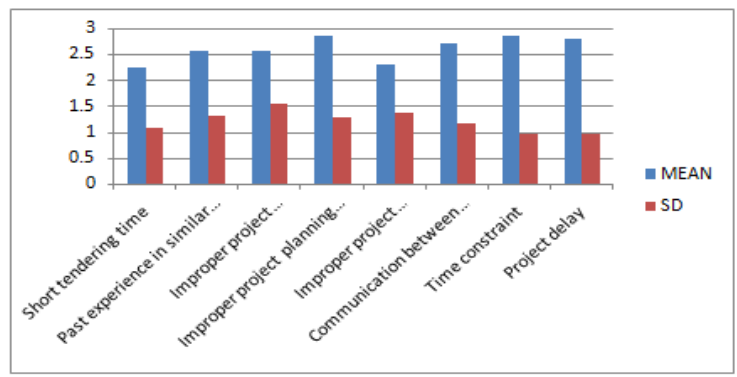

Figure - 4 Bar Chart for Management Risk

\section{V.CONCLUSION}

To the extent India is concerned hazard the board is as yet another word in the development part and this ought to be changed as quickly as time permits. Coming up next are the resolutions from this examination work.

Due to climatic condition there are many hazard is been looked in site, by defensive measure we can control the hazard in site.

Short offering time likewise be fundamental hazard looking in certain association [35-36], Due to brief time there is issue in planning Bill of Quantity.

\section{REFERENCES}

1. Sathish Kumar, K., Vinothkumar, S., Venkatakrishnaiah, R. \& Mohan, S.J. 2019, "Experimental investigation on rehabilitation of corroded concrete beam specimens", International Journal of Civil Engineering and Technology, vol. 10, no. 1, pp. 2949-2955.

2. Kanchanabhan, T.E., Krishnaiah, R.V., Dayakar, P. and Mani, A., 2019. A detailed study on green building concept in construction industry. International Journal of Civil Engineering and Technology, 10(1), pp. 2944-2948.

3. Mugilvani, P., Murugan, S.T., Kaviya, B. and Sathishkumar, K., 2019. Experimental investigation on nano concrete. International Journal of Civil Engineering and Technology, 10(1), pp. 907-912.

4. Vinothkumar, S., Sathishkumar, K., Anish, C. and Rajesh, S., 2019. Characteristic strength of concrete by partial replacement with sawdust and waste ceramic tiles. International Journal of Civil Engineering and Technology, 10(1), pp. 2821-2829.

5. Chitra, R., Thendral, S., Arunya, A. and Mohan, S.J., 2019. Experimental study on strength of concrete by partial replacement of fine aggregate with saw dust. International Journal of Civil Engineering and Technology, 10(1), pp. 2766-2769.

6. Mani, A., Meikandaan, T.P., Gowrishankar, P.G. and Kanchanabhan, T.E., 2019. A study on treatment of industrial effluent (dyeing) using moringa oleifera, tamarina indica as coagulants. International Journal of Civil Engineering and Technology, 10(1), pp. 2796-2811.

7. Frank Stephen, S., Chockalingam, M.P., Nalanth, N. and Lekshmy Raghavan, P., 2019. Study on the fresh state properties of self compacting concrete modified with recycled concrete aggregate International Journal of Civil Engineering and Technology, 10(1), pp. 1205-1212

8. Dayakar, P., Raman, K.V., Arunya, A. and Venkatakrishnaiah, R., 2019. Study on strength properties of sand by biocementation with eggshell. International Journal of Civil Engineering and Technology, 10(1), pp. 2770-2785.

9. Shendge, R.B., Chockalingam, M.P., Saritha, B. and Ambica, A., 2018. Swat modelling for sediment yield: A case study of Ujjani reservoir in Maharashtra, India. International Journal of Civil Engineering and Technology, 9(1), pp. 245-252.

10. Meikandaan, T.P. and Hemapriya, M., 2017. Use of glass FRP sheets as external flexural reinforcement in RCC Beam. International Journal of Civil Engineering and Technology, 8(8), pp. 1485-1501.

11. Harini, A.T., 2017. Experimental study on utilisation of ceramic wastes in concrete. International Journal of Civil Engineering and Technology, 8(8), pp. 1346-1352.

12. Ambica, A., Sartiha, B. and Anbarasan, R., 2017. Groundwater quality assessment using water quality index and GIS, Maduravoyal, Chennai, India. International Journal of Civil Engineering and Technology, 8(8), pp. 1375-1381.

13. Aswathy, M., Saritha, B. and Chockalingam, M.P., 2019. Degradation of anionic dye using Fe/Tio2 composite by photocatalysis. International Journal of Innovative Technology and Exploring Engineering, 8(9 Special Issue 3), pp. 788-791

\section{AUTHORS PROFILE}

P. Dayakar Associate Professor, Department of Civil Engineering, Bharath Institute of Higher Education and Research, Chennai, India.

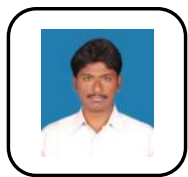

K. Venkat Raman Assistant Professor, Department of Civil Engineering, Bharath Institute of Higher Education and Research, Chennai, India.

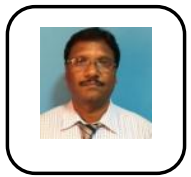

R.Venkatakrishnaiah Associate Professor, Department of Civil Engineering, Bharath Institute of Higher Education and Research, Chennai , India. 